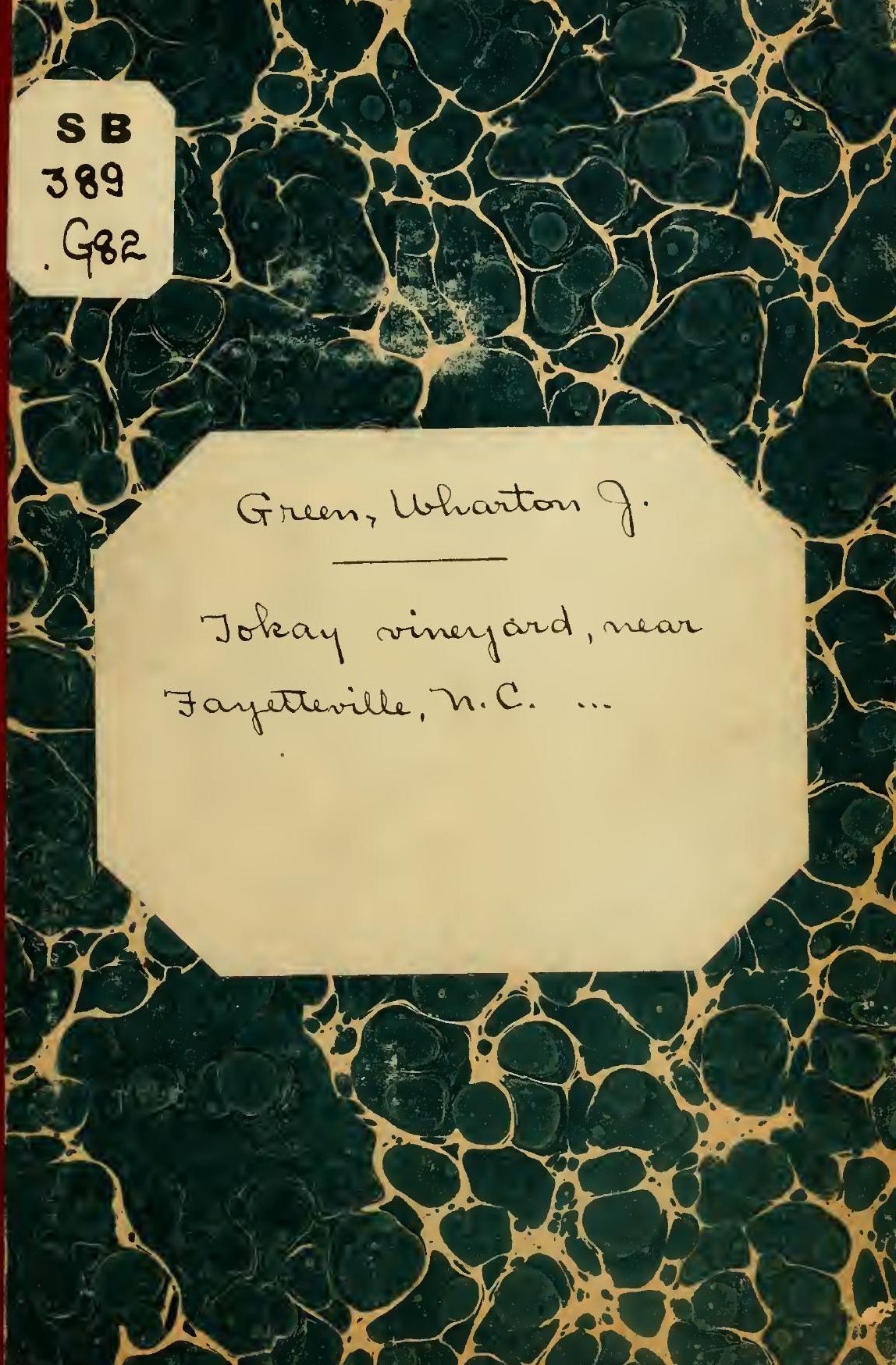


ช 



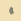




S B

With canplingines

389

G 82

\section{TOKAY VINEYARD,}

NEAR

FAYETTEVILLE, N.C.

WITH

ESSAY ON GRAPE-CULTURE

BY THE PROPRIETOR.

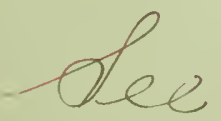




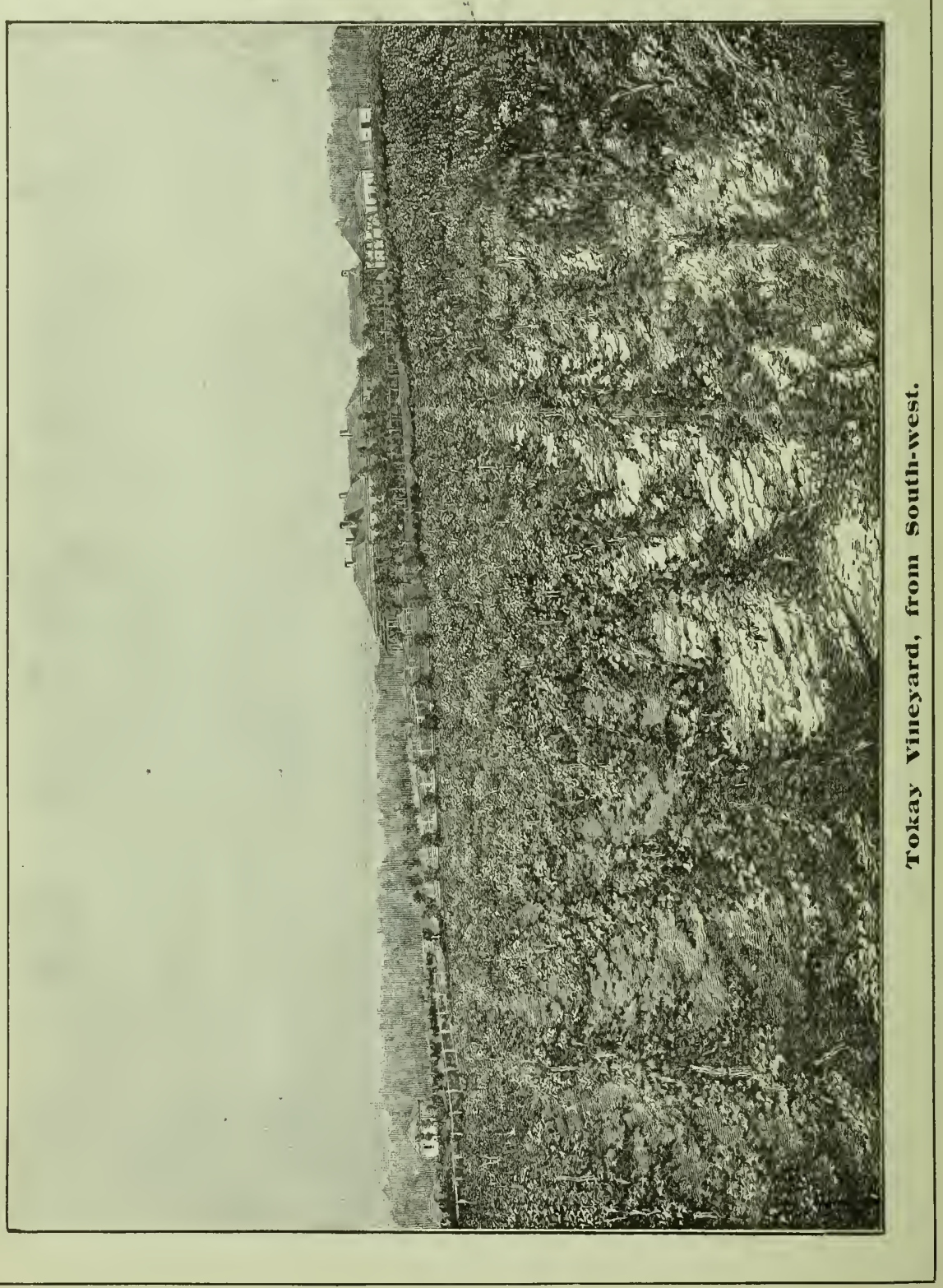




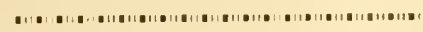 \\ TOKAY VINEYARD,}

NEAR

FAYETTEVILLE， N.C.

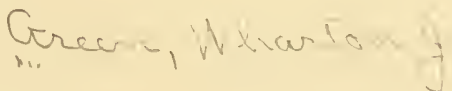
WITH

ESSAY ON GRAPE-CULTURE

BY THE PROPRIETOR.

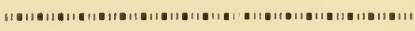




\section{$3=\geq 8$ \\ G82}

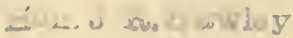 \\ 7. 103}

$$
\because \vdots \vdots
$$




\section{TOKAY VINEYARD, \\ FAYETTEIILLE， N.Г，}

$\mathrm{F}$ one-half of what has been said and published in praise of 1 this now celebrated spot and its products, by the press and by visitors generally, were collated in book-form, it would make a good-sized volume.

Such is foreign to the purpose. But the writer may be pardoned for culling a few of the many compliments and complimentary descriptions so literally showered upon them.

Curtailing that which is purely personal, he presents below a part of an article from "The Wine and Fruit Grower" (published in New York) of February, 1883.

"Tokay Vineyard. - Tokay Vineyard is situated three miles and a half north of Fayetteville, N.C. It is said to be the largest single vineyard this side of the Rocky Mountains; and, speaking after a personal inspection, we pronounce it one of the loveliest locations that can be found anywhere on the continent. Such is the concurrent testimony of almost all visitors.

"Situated on a broad, undulating tableland on the Cape Fear River, some two hundred feet above its ordinary level, and one hundred and fifty above the rich alluvial plantations on the opposite bank, the eye takes in a semicircular horizon of twenty odd miles in radius.

"Nature has done much for it, art more. With upwards of one hundred acres in bearing vines, which is being rapidly extended 


\section{TOKAY VINEYARD, FAYETTEVILLE, N.C.}

from year to year, and every thing kept as neat and trim as a lady's flower-garden, with its young orchards of choice fruits, fishponds, numerous springs of the purest water, and running brooks, it is, simply as a thing of beauty, utility being left out of the account, well worth a day's journey to behold.

"But its hospitable proprietor has blended the utile ct dulce in harmonious whole, and all around betokens a refined taste combined with an eye to the end.

"He is an enthusiast in his vocation, both on moral and economic grounds; and his highest ambition seems to be, that he may hereafter be the accredited pioneer of an inclustry which he is sanguine is destined at an early day to be the leading one of his State.

"In his estimate of adaptability-latitudinal, climatic, and meteorologic - he concurs in the opinion of the celebrated Nicholas Longworth of Cincinnati (the true father of viticulture in America), that North Carolina is the natural habitat of the vine, and the normal vineyard of the Western World. With a courage and a will deserving of success, he proposes to prove it. If he does it, the two-blades-of-grass hero, or he who is capable of commanding a hundred thousand men, is distanced in the race of public benefaction.

"That vine-growing is destined at an early day to assume the proportions which it has long maintained in the older world as its leading industry, none can doubt who are cognizant of the ravages of the tiny insect termed phylloxera, more dreaded by the vine-planter than an army with banners.

"The native American wine-grapes are proof against the scourge, at least those of the astivalis class. 'Tokay' is planted almost exclusively of varieties of that family, numbering some thirty or forty altogether, including the Scuppernong and its offshoots (the Meisch, Flowers, etc.), the Norton, Cynthiana, Hermann, Martha, 


\section{TOKAY VINEYARD, FAYETTEVILLE, N.C.}

Delaware, Ives, Cottage, Telegraph, Champion, Rulander, Herbemont, Concord, etc.; naming the last in the order of merit, as adlapted to the soil and climate of the place.

"Col. Green fully indorses all that has been said in praise of the Norton and Cynthiana, and pronounces them the finest red-wine grapes in the world. Such was the award at the Vienna, and at the Paris Exposition they received very high commenclation.

"The wine-product for the season before the last was about twenty-five thousand gallons. With an equally favorable one this year, the proprietor is sanguine that the yield will exceed forty thousand gallons, owing to increased growth of the olcher vines, and acreage in new ones. His cellars have a storage-capacity of fifty or sixty thousand, and are now about half full. These wines have been pronounced by Dr. Sayre of New York, Dr. Gardiner of the army, and other high authorities, the finest native wines they ever drank. They have been awarded the gold medals and all the first premiums, at four last State fairs, and three first at Atlanta.

"The dwelling is a large, commodious, and comfortable structure, with little pretension to architectural elegance, but well adapted to the use of a gentleman of active business-habits.

"It is lighted with gas macle on the place, and supplied with pure spring water by means of a steam pump half a mile off. The proprietor is an enthusiastic disciple of Izaak Walton, and has four or five ponds well stocked with the most approved varieties of fish.

"Besides the vineyard proper, there are about seven hundred acres additional, with a fine saw-mill attached to the place, belonging to, and forming part of, the plantation."

"The Wines of TokaY. - It may not be amiss in this sketch to take a critical look at the wines produced at this vineyard. Indeed, it will doubtless be expected that a thorough and truthful 


\section{TOKAY VINEYARD, FAYETTEVILLE, N.C.}

criticism should be passed upon them, to round it off and give it real value.

"Before entering upon this, we remark that what is said of these wines must apply, so far as general principles and characteristics are concerned, to the wines of the whole South, and will most likely be taken in many quarters as an authoritative exposition of the relative character and value of these wines. We therefore feel that a just regard for the interest of so large a portion of the country, and the correlative interests of other portions, requires of us considerable circumspection and caution in setting up what ought to, and must if true, stand as historical facts upon the viticulture of such portion.

"To begin, therefore, we observe that the wines made at Tokay vineyards are of a dual character. The red and white wines made from the grapes that flourish in the States farther north are to be found here in perfection; because the long and hot season secures a full ripening of the fruit, carrying the must up to a high degree, thereby insuring sufficient saccharine matter to produce the requisite quantity of alcohol without the addition of sugar.

"Of this class, the Norton and Cynthiana, the Delaware and Martha, etc., constitute the bulk. As these wines are well known to everybody, we need only add that nearly one-half the vineyards are taken up by these vines, and chiefly by the two first; also that the new plantings are almost wholly made of these varieties.

"Of the other class - the Scuppernong, and its children the Flowers and Meisch, constituting an entirely distinct and widely different group, peculiar to the States south of the thirty-sixth parallel of north latitude - an extremely interesting essay might be written, and indeed, to do it justice, much more than we can crowd into this brief sketch.

"The natural home of this grape is in all the seacoast States 


\section{TOKAY VINEYARD, FAYETTEVILLE, N.C.}

from North Carolina to Texas, including Arkansas and Mississippi. It seems to prefer the sandy coast-lands, though it flourishes magnificently on any good cotton-land. It was discovered on Roanoke Island three hundred years ago, where the original vine - covering more than an acre of arbor, and bearing fruit enough yearly to make from two thousand to twenty-five hundred gallons of wine is still living. It is said the first wine made on this continent was made from this vine.

"Tokay Vineyards, at the time Col. Green purchased the property, had about sixty acres of these vines in bearing; viz., Scuppernong, Flowers, and Meisch. These were trained in the usual way prevalent throughout the Southern States, on arbors, and have produced from fifteen to twenty-five thousand gallons of wine yearly since.

"The wines as prepared at the Tokay cellars are the Dry Red and Dry White, and Sweet Red and Sweet White, and are so denominated.

"In general characteristics they resemble the Spanish and Madeira wines; and the Sweet White is not unlike the California Mission, though much more delicate in bouquet, and, when given proper age, approaches the closest to a fine old Madeira of any wine yet produced in this country. This wine will constitute a good basis for a sherry wine when made with that view; and we have seen some samples of such from these vineyards which strongly resembled Old Brown Sherry, and would do credit to any gentleman's sideboard and private cellar. Other samples, again, made from the Flowers, - a black Scuppernong seedling, - as a dry wine, resemble certain red wines of Hungary already highly esteemed in this country, and as a sweet wine bears a close relation in character to Spanish Red.

"The manner of handling these wines at Tokay, under the able management of the superintendent, Mr. McBuie, is careful, sys- 


\section{TOKAY VINEYARD, FAYETTEVILLE, N.C.}

tematic, and thorough to a degree, and calculated, if due age is given, to bring out their good qualities.

"As to the methods of training the Scuppernong vines, as practised at Tokay Vineyards, we may be pardoned for saying, that it is not the system to bring out the full capacities of the Scuppernong as a wine-grape, being the old-time arbor system in vogue throughout the South.

"By that system it is not possible to produce a must weighing over sixty-five degrees Oechle's, and frequently it drops as low as sixty degrees. On the other hand, some of our correspondents who have adopted the high-trellis system, and pruned the vines, and fertilized them, as other species usually are, have informed us that they have annually obtained a must weighing from eighty to eighty-five degrees. Of course it will be seen from this, that in any event it will be necessary to add sugar to produce a wine that will stand up in any climate, and bear shipwreck anywhere; or to add salicylic acid. This is true of many other good wine-grapes, both here and in Europe.

"The following is the analysis of the North-Carolina Scuppernong, as made by the chemists of the Agricultural Department at Washington :-

Specific gravity, I.0I22; per cent alcohol by weight, I4.I4; per cent alcohol by volume, 18 ; per cent total residue, 8.38 ; per cent total ash, I.04; per cent sugar, 6.67 ; per cent total acid as tartaric, .74I ; per cent fixed acid as tartaric, .459; per cent volatile acid as acetic, .234.

"A study of this table shows that the wine possesses in a comparatively high degree the vinous properties of a good healthful wine. It certainly is highly esteemed by the medical profession throughout the South, and is often prescribed by them where a gentle stimulant or tonic is needed, and especially in certain kidney ailments, with the utmost confidence and faith. 


\section{TOKAY VINEYARD, FAYETTEVILLE, N.C.}

"The grape is ironclad against every insect pest at present known, healthy, prolific bearer, of rapicl, robust growth, extremely long lived; and, when a better method of training the vines is adopted, a much higher place in the scale of American winegrapes awaits it."

This from "The Wilmington Journal," June 8, I 883 :-

"A neat but modest cottage, resting on the brow of a gradually sloping hill, surrounded by well-kept grape-vines and young fruittrees, is the home at Tokay, near Fayetteville, of Hon. Wharton J. Green, congressman-elect from the Third North-Carolina District. It is one which might well be considered the ideal home of a poet ; being beautifully located, and handsome in its surroundings, nestled as it is in the midst of the beautiful Tokay Vineyard, surrounded by almost innumerable trellised grape-vines of equal height, whose verdure embraces every tint of spring's first harbinger of abundant yield. The unpretentious cottage of our congressman is truly a beautiful oasis of peace and tranquil repose in this ever progressive world.

"Chaste and beautiful statuary is gracefully placed about the grounds immediately surrounding the home which Col. Green has made for himself and family. ...

"After being warmly welcomed by Col. Green, and resting in the home of our congressman, we were shown over the grounds, and through the vineyard.

"Tokay consists of about two hundred acres of fertile land, which is under a high state of cultivation, with much more outlying land, which will be taken in and cultivated, as occasion requires, in carrying out the ideal and model vineyard of Col. Green.

"From an observatory-landing on the eastern end of the winehouse a most magnificent view of Tokay and the surrounding 


\section{TOKAY VINEYARD, FAYETTEVILLE, N.C.}

country can be had. The eye follows in every direction the soft verdure of the trellised vines down the graclually sloping hills; and when looking in a southerly direction the slope is gradual and gentle, until the eye is arrested by the curving branches on the Cape Fear River, and the bluffs on the opposite bank, whose sides and tops are covered by honeysuckle, wild flowers, and the stately water-oak, maple, ash, and the immense variety of trees and various foliage for which the river-banks are noted. Looking a little farther to the south, the church-spires and the buildings in the ancient and historic town of Fayetteville, as it rests languidly in the hills which surround it, and through which the gurgling waters of the Cross Creek flow, can be seen. Continuing our ramble through the grounds, we saw and examined the gas-house, the steam pump which supplies the residence with water, the foundation of the old wine-house which was destroyed by Sherman's renegades, and drank from the spring, which is noted for the purity of its water. We next visited the fish-ponds, which Col. Green has spent much time in bringing to their present excellent condition. These are five in number; and each one is well stocked with the choicest fish, which seem to know their owner's step and voice, and readily come to the edge of the ponds to receive food from his hands.

"Another new propagating-pond is being made, which will increase the capacity for raising young fish.

"Col. Green seems only to have improved upon the natural advantages offered, and in so doing has strenuously avoided every thing which would tend towards an artificial appearance. A circuitous route brought us back to the wine-house and vaults, which we were shown through. Here we found over forty thousand gallons of wine of different vintages. The vaults are kept at the same temperature during the entire year, and from them some of the best wines made in this country are taken. 


\section{TOKAY VINEYARD, FAYETTEVILLE, N.C.}

"A highly competent judge and dealer in imported wines in New York has written to the superintenent of Tokay, telling him that the wines sent him were equal to the best imported wines he received.

"Col. Green is having a new peach and apple orchard planted, with improved varieties, and is constantly making additions to his vineyard, notwithstanding the fact that Tokay is alreacly one of the largest vineyards in this country. The gates of Tokay are always open to visitors ; and during the harvest all are welcome to partake of the luscious fruit of the vine, while the sick and absent ones are never forgotten by the genial host of Tokay.'

"The Raleigh News and Observer" says, -

"It has been my great pleasure to visit this most lovely spot, the Tokay Vineyard, by invitation of Col. Wharton J. Green. I venture the assertion, that it is one of the loveliest spots in the State; and, with the improvements Col. Green is making, in a year or two more it will be a place of as much beauty and interest as any $I$ know of in the South. There are now one hundred acres under the cover of grape-arbors, and vines of every variety of grapes.

"The view from the top of the wine-cellar is not to be surpassed., The Claret and Scuppernong are superior to any I have ever tasted. Col. Green makes a Dry Scuppernong, which must meet a ready sale. And, to my taste, the Claret he makes is as good as any I ever clrank. The colonel has four valuable fish-ponds, with every variety of fish, consisting of carp, speckled trout, perch, etc. He has a gasometer on his place, and his premises are lighted with gas."

Scores of certificates from prominent parties, and good judges of wine, might be added in support of the purity and excellence of 


\section{TOKAY VINEYARD, FAYETTEVILLE, N.C.}

the wines of Tokay. A few, however, will suffice as samples of the rest. Clipped from "News Observer:" -

"The Tokay Wines. - Dr. Louis A. Sayre of New York, a famous physician, has written a letter to his warm friend, Dr. Eugene Grissom, in which he speaks in the highest terms of the wines from the celebrated Tokay Vineyard of Col. Wharton J. Green, near Fayetteville. In his letter Dr. Sayre says, 'You will pardon me for not thanking you sooner for your beautiful present of native wine, which a number of friends tried on Christmas Day, and pronounced equal, if not superior, to the finest Rhine wines. I had no idea such wine was made in this country, and I am very proud of it.'"

Professor Wheeler of United-States Military Academy:-

IVest Point, N.Y., April 25, $188_{3}$.

Col. Wharton J. Green, Tokay Vineyard, Fayetteville, N.C.

My dear Sir, - I have received the last half-barrel of wine which your superintendent, Mr. McBuie, shipped me, in compliance with your instructions to fill my order, and have given it a fair trial. I consider this last shipment as good as, if not superior to, any I have before received.

I have now been using this brand of wine, Sweet Meisch, upon my table for my family for a period of three years. It was first recommended to me by Dr. Hughes of Newbern, N.C., and has proved a pure, wholesome, and excellent wine in every respect. I have no hesitation in recommending this wine to all persons who are desirous of having upon their table a wholesome and healthy drink. When persons cannot drink freely of cold water - as, unfortunately, there are many - without suffering from its effects, I know of nothing that can supply its place like your native wines, so free are they from the adulterations and impurities of the foreign stuffs which characterize the importations of the day from abroad. I have found this wine to be beneficial in its effects, and in fact a food for the members of my family.

Most truly yours,

J. B. WHEELER. 


\section{TOKAY VINEYARD, FAYETTEVILLE, N.C.}

\section{Judge Woodbury of Boston writes:-}

Boston, May 8, 1883 .

DEAR SiR, - The box with native Claret and Scuppernong from your vineyard has reached me at the Parker House. Summoning assistance from some of its noted connoisseurs, it had a thorough trial. and we found the Claret not to be surpassed by any American wine of its kind we had ever met; and in richness of aroma, and fruity quality, it astonished those only acquainted with the wines of Europe.

The Sweet Scuppernong we found smooth, fruity, and a capital ladies' wine. With a continuance of the care and skill in its preparation that your wine evinces, I think this may be made to take the front rank among all the native wines; and when it gains dryness by age it will greatly resemble the grape-juice of the south side of Madeira. I had no idea the soil near Fayetteville was so favorable for the vine-culture, but I now understand the judgment of those committees who have awarded medals and prizes to the products of the "Tokay Vineyard."

I am very faithfully yours,

CHARLES LEVI WOODBURY.

Hon. Wharton J. Green, Fayetteville, N.C.

Dr. Gardner of the army writes :-

W. J. Green, Esq.

Fort Davis, Tex., May 28, 1883.

Dear Sir, - It gives me great pleasure to add my testimony to the many you have already received regarding the excellence of your wines. When all are so good, it is hard to discriminate ; but those which especially tickled my gustatory nerves are the Claret, the Dry Scuppernong, and the Sweet Meisch.

I am no longer a juvenile, and during the past twenty years have drunk considerable imported Claret; and, to my experience, you ${ }^{\circ}$ Claret has a much pleasanter effect, both on the palate and on the system generally, than either the imported Margaux or the Medoc.

The Sweet Meisch is a universal favorite with ladies. I have never offered it to a lady who was not pleased with its delicate bouquet and flavor. And on the same grounds it is much esteemed by invalids, while its percentage 


\section{TOKAY VINEYARD, FAYETTEVILLE, N.C.}

of alcohol is not so great as to render it too stimulating. The Scuppernong, too, is a wine that has warm recommendations. Its delicious flavor, perfect purity, and entire absence from any hurtful effect upon the system, will, I know, soon cause it to come into general use wherever its qualities are known.

I have already recommended your wines to many of my friends; and I shall feel that I have only done my duty, if my commendations help in the least to establish the use of pure native wines, and to decrease the consumption of the vile foreign concoctions sold as the juice of the grape.

I am, sir, very respectfully your obedient servant, W. H. GARDNER, M.D., Major and Surgeon, U.S. Army.

From Capt. Conrad of Tenth Infantry, U.S.A. :-

Hon. W. J. Green.

Fort Randall, Dakota, July 26,1883 .

Sir, - It has been about two years since I first met with the wines of Tokay Vineyard; and after quite a trial of both the Claret, Sweet Meisch, and Sherry you manufacture there, I am pleased to state that I consider them vastly superior to any other native wines I have ever used. In fact, I consider your Claret as unequalled by any other maker, either abroad or at home. It is a rich, pure, fruity wine, of delicate taste and odor, and I believe a more healthful wine than any other 1 have used on my table.

I have noticed also its superiority over California Claret, in the fact that it can be kept quite a number of days in a decanter, and apparently suffer no deterioration from partial exposure to the air; while all the California Claret I have used has somred by the second day. I take pleasure in recommending your wines to all who desire a pure, honest article.

Yours respectfully,

J. A. CONRAD, Captrin Tenth Infantry.

The late Henry Nutt of Wilmington says, "Send me another case of your Claret. I unhesitatingly pronounce it not only equal to, but in my sober judgment superior to, the best imported article I ever drank." 


\section{TOKAY VINEYARD, FAYETTEVILLE, N.C.}

Capt. Tomkins of the army :-

114 EASt Igth Street, New York, May 21, I883.

It affords me pleasure to testify to the very excellent qualities of the Scuppernong wine from the Tokay Vineyard of Fayetteville. The wine, both sweet and dry, is far superior to any of the kind I have ever tasted; and I feel assured it will rapidly take a prominent rank among the native wines of this country.

J. S. TOMKINS, Captain U.S.A.

Lieut. J. T. French, jun., writes :-

West Point, N.Y., April 23, 1883.

. . . It gives me pleasure to say that I consider the Sweet Concord wine sent me from Tokay Vineyard, and again this spring, the most satisfactory wine of its kind that I have ever tasted. If the Claret from your vineyard is as good, I am sure that the army mess of this post can easily be made a customer, and their indorsement will be worth something to you. . . .

I would like to see the absurd notion, that wine can't be good unless it is imported, shown up in its proper light.

Very respectfully,

J. T. FRENCH, Jun., ad Lieutenant Fourth Artillery.

\section{TOKAY WINES.}

The award of the Atlanta Exposition reads :-

"Ives Seedling Wine. Best on exhibition, and premium of $\$ 5$ recommended.

"Norton's Virginia Vine. Sparkling wines and still wines. Best on exhibition, and especially recommended for table wine. Premium $\$ 5$.

"We find also that Col. W. J. Green has the best collection of sparkling wines, for which we recommend an award of the first premium of \$I5. His sparkling Scuppernong ranks with the best native Champagne. Also second premium for best collection of still wines. We found in these 


\section{TOKAY VINEYARD, FAYETTEVILLE, N.C.}

collections samples of wine of very superior quality, equal to the best imported wines."

The last four State Fairs have awarded all the first premiums, including three gold medals, to the wines of Tokay: so have the Fruit-Growers' Fairs of the State, and all the County Fairs, wherever it has entered for competition. 


\section{An Essay on American Grape-Culture.}

IF he who causes two blades of grass to grow where but one grew before is greater than he who winneth a battle, surely he who causes a new industry to spring into existence where it was unknown before is not without service to his fellow-man.

The pioneer is usually a public benefactor, be it a Columbus, a De Soto, a Raleigh on unploughed seas, a Boone in the wilds of Kentucky, an Arkwright, Fulton, Faraday, Maury, Morse, or Edison in the fields of science, or he in agriculture who demonstrates the feasibility and profit of growing valuable products in localities before considered unsuited. In either case the essential elements of the hero - nerve, penetration, self-reliance, and contempt for the sneers of witlings - are indispensable to success. And we hold that the humanizing agents of advancement are infinitely more to be honored than the representatives of the destructive or brutalizing idea.

If a Krupp, an Armstrong, or a Gatling are to be held in honor of men for their terrible engines of destruction, who shall gainsay at least equal praise to him who contributes in any wise to the amelioration of the race, or the development of his State? Such, as a rule, are not without honor, save in their own country. There, contempt is usually their portion.

Nicholas Longworth setting out his little vine-patch on the hill- 


\section{TOKAY VINEYARD, FAYETTEVILLE, N.C.}

slopes of the Ohio overlooking Cincinnati, was probably as much an object of ridicule to the wise-acres about him as was the first arkwright whilst preparing for the big freshet. The one, however, became the second founder of the human family, and the first recorded patron of the wine. The other, although he ever led an active life, and accumulated a colossal fortune, always maintained, and posterity will affirm, that the vine-patch constitutes his chiefest claim on the gratitude of those who are to come after. And why? Others had planted vine-patches before, and rested in the shade thereof? Most true. But none in the New World had planted with the purpose and intent of working out a mighty problem, the solution of which was considered as chimerical as the quadrature of the circle.

He it was who answer gave to the sceptical query of quid muncs, "Can wine be made in America?" His experimental answer was no doubtful affirmative, and is to-day worth annual millions to his trusting and confiding followers. It will, in the no distant future, be worth untold millions to his countrymen in the moral, economic, hygienic aspect of the case. The proposition critically examined, and none but bigots will refuse him a niche amongst the world's benefactors. Reason why? This strong conglomerate race to which we belong ever has, and, as much as it is to be deplored, probably ever will use stimulants. Then give us the least pernicious. Is it corn-juice, or is it grape-juice? Upon answer to this hingeth answer, "Was Nick Longworth a benefactor?" Science tells us at the threshold, that alcohol evolved by fermentation is less noxious than that of clistillation.

O "ye unco guid!" follow me to the vine-clad hills of sunny France, the Rhenish slopes, the Spanish plains, Italian arbors, and terraced hillsides of the Sicilies, Teneriffe, and Madeira, where the vine has, or had, an established home, and tell me if amongst the festive bands of youths and maidens returning from the lus- 


\section{TOKAY VINEYARD, FAYETTEVILLE, N.C.}

cious clusters and well-stocked cellars, after their clay's work is done, you observe a beastly Bacchanal, half man and half goat, Silenus-like, tottering under an excess of alcoholic dead weight. And yet I invite you to the lands where the juice of the fruit of the vine is almost as abundant, cheap, and free as Nature's beverage. Let us now wend our way to the lands where the grape groweth not, or is just beginning to grow, - Russia, Sweden, Norway, England, Scotland, Ireland, Mexico, and even our own favored country. Mark the contrast, and answer make according. It seems to be an inscrutable law of nature, that, as wine increases, drunkenness diminishes. As regards the United States, it has lately been stated officially, that, population consiclered, there is not half the amount of distilled spirits drunk at this time that there was twenty years ago. Whilst the advocates of a high direct tax on the article - in spite of the admission of parliamentary committees to the contrary, in the case of Scotland and Ireland, where the experiment of a tax supposed to be prohibitory has had a fair test and trial - are clisposed to claim all the credit for the reduction in consumption, the native wine-grower modestly puts in his claim, and holds that the largely increased production of home-made cheap wines accounts, more than all things else, for the corresponding falling-off in consumption of gin, rum, brandy, whiskey, etc.

From the earliest recorcled times, the cultivation of the vine, and the expression and fermentation of the juice of the grape, has been one of the recognized great industries of the world. After the indispensable "staff of life," it has been the chiefest pillar of national prosperity for more gieat States than any other one agricultural staple that can be named.

During the long period that "The Eternal City "was the recognized mistress of the world, and when the Roman Legions bore "the eagle" from the Pillars of Hercules to the Euphrates and 


\section{TOKAY VINEYARD, FAYETTEVILLE, N.C.}

Indus, and from the equatorial south to the frozen north, wine was the established market and money crop of that puissant people. The vine was the foster-child of the senate, of consuls, and of tribunes. The annual product was immense, and freely was it consumed. At home and in camp it was drunk like water, and yet drunkenness was not the prevailing vice of Rome. That its use was not enervating, we have but to turn to the recorded achievements, the unparalleled endurance, of her matchless soldiery, to have all doubts resolved. The reason is obvious. They made a pure article, and drank nothing stronger. In the heyday of the republic, before national decay, the inevitable result of personal decadence, set in, honesty was no less the rule in Rome than were patriotism, courage, and frugality. Short weights and measures, counterfeiting and adulterations, stamped the guilty party with the Latin synonyme of the good old English word "scoundrel;" and swift and terrible penalty followed. The diabolic arts and playful tricks of modern chemistry, by which harmless simples are so blended and compounded as to prove most noxious and destructive to human liealth and life, were then unknown on the banks of the Tiber. Pure wine and healthy food, neither of which had undergone the manipulations of an "expert," were the only sort sold in the markets of Rome; and a brave, vigorous, simple, and healthy race was the result.

Unlike the citizens of "the great modern republic," those of "the great ancient" had nothing more terrible to apprehend than a Carthaginian arrow, or the javelin of a Gaul. Grim distrust had no seat at the festal board to whisper with every crook of the elbow, "Do you know what you are putting in your mouth ?" But to return from this digression. The vine to-day (or, rather, yesterday, before the terrible phylloxera began to work upon it) is or was the source of the material prosperity of the nations of Southern and Central Europe. 


\section{TOKAY VINEYARD, FAYETTEVILLE, N.C.}

In France it had for centuries maintained proportions which dwarfed all other pursuits, the yearly crop largely exceeding in market-value that of our much vaunted textile fabric, cotton.

Has inebriety kept pace with yearly increasing product in those countries? It has, but in the inverse ratio. The traveller will tell you that it is a rare sight, that of a drunken man in the wine-producing countries of the Old World. If such be a fact, does it not behoove the philanthropist to pause and stick a pin, and ask the reason why? If fact it be, taken in connection with another, viz., that the immaculate Saviour of mankind turned water into wine at the wedding-feast, it surely ought to silence those self-sufficient and narrow-minded bigots who cry out against the morality of grape-growing and wine-nuaking.

It is, of course, a new industry in the Now Horld, but in the last few years has been making headway with the strides of a giant, and bids fair, at a no distant day, not only to drive the refuse stuffs of the foreign vineyardist out of our own markets, but to compete with him in neutral ones, if not in those under the shadow of his own vine.

For generations its introduction and development were retarded in our country by the ex cathedre scoff of the Old-World culturist, that wine could under no circumstances be macle on this side of the Atlantic, and the implicit credence given the statement by would-be beginners in the experiment, as well as by winedrinkers themselves, who had to be educated up to the point of impartial trial, and to put their own palate on the witnessstand, instead of placing implicit reliance on the damnatory verdict of an adverse and partial jury. That point has now been reached, and it is a great point gained. According to the "Report of the Chief of the Bureau of Statistics," published by the United-States Government, the amount of native wines consumed in this country is over twenty-five per cent of all that is 


\section{TOKAY VINEYARD, FAYETTEVILLE, N.C.}

used ; and the supply and the demand are increasing with accelerated speed.

Whilst there is undoubtedly a certain class of Americans, sui gcncris, who prefer to set up as comnoissenrs, and who, to maintain their self-complacent assumption of superior taste, will persist in being cajoled and "put upon" by foreign pretenders, and native dealers in forcign wares, nevertheless, the great bulk of our people are too practical, common-sensed, and matter-of-fact to continue to take forever foreign notables or foreign wares at the exorbitant valuation which they put upon themselves and their products. A little while back it was impossible to get a bottle of native wine at any of the high-priced and fashionable eating-houses of the large cities. Now few of them can afford to be without them. The repeated demand of their customers for a pure, low-priced native beverage has remedied the omission on their shelves.

Doubtless another reason for the result stated is the constantly diminishing European supply, owing to the ravages of that constantly increasing pest of the Old-World vines, previously referred to as "phylloxera," which are rapidly sweeping out of existence the old recognized source of supply. This tiny insect, which attacks the young rootlets of the vine in myriads, denudes them of their bark, and leaves them to die a lingering death. Already whole districts heretofore devoted exclusively to wine-culture have been virtually abandoned for that purpose. Governments have offered immense rewards for a remedy, but all in vain; and the old proprietors are now driven to the necessity of introducing native American vines of the heretofore by them despised restizalis family, which are phylloxera-proof, owing to their thin coating of bark, upon which the insect can make no headway. If thcy can make a wine out of our own grapes, the question may well be asked, "Why can w' not do it with cducated labor?" George 


\section{TOKAY VINEYARD, FAYETTEVILLE, N.C.}

Hussman, high authority, predicts that in ten years the European or Asiatic grape will virtually cease to exist. Why, too, should we not then transfer this rich argosy, or rather this close monopoly, to our own shores, and hereafter furnish the Old-World folk with drink, as we are now cloing, to a considerable extent, with meat and bread?

Mr. Nicholas Longworth, the true father of American viticulture, stated over thirty years ago that our own State, North Carolina, was the normal habitat of the vine on the western hemisphere, the natural vineyard of the continent.

Should not the govermment cncourage the effort?

Such we hold to be its cluty no less than its interest. The winegrower demancls no prohibitory protection against foreign competition, although representing an industry but yet in its infancy. Natural causes will soon do that. But he thinks he has the right to demand that unnatural restriction, such as license-tax from the retailer, should straightway be abolished, as calculated to hamper and curtail his sales to that class. There is no good reason why it should be retained. By detaching it from the same category with distilled spirits, the sale of these last would not be perceptibly affected, and hence neither would the revenue from that source.

Why, then, the question may well be asked, should this manufactured product of the soil be subject to inviclious tax more than the products from sorghum, jute, hemp, or oil-seeds? No better reason than existing usage can be assigned for the retention of such an unjust and unwise excise. It has been estimated that the people of this country are taxed indirectly no less than truclve hundred and fifty millions anmually to encourage the manufacturing interests of the land. If their juvenility can justify the claim to governmental protcction to such an inconceivable extent, surely this other and newer industry may demand in common equity, both for itself 


\section{TOKAY VINEYARD, FAYETTEVILLE, N.C.}

and for the sake of national prosperity, that all restrictive legislation as affecting itself shall at least be abrogated.

The vine first loomed into importance in the New World on the banks of the Ohio, although the Spanish Jesuits had cultivated it extensively a century or two before in New Mexico and California. To-day it occupies a prominent place amongst the leading industries of Ohio, Missouri, Texas, California, New York, New Jersey, and Virginia. North Carolina has been laggard in its development, although the birth State of many of the most approved varieties, and especially of the grape prodigy previously spoken of as "the Scuppernong," whose discovery is coeval with Caucasian rule on the continent. It is essentially a tropical, or rather semitropical, plant, and will not flourish north of $36^{\circ} 30^{\prime}$ north latitude, and, unlike too many of Carolina's sons, prefers its native State to any other. Its fruit fresh from the vine is conceded, by nearly all who have ever tried it, to be one of the most delicious in the world. It is one which grows upon the palate, and increases in popularity upon better acquaintance. Besides its nutritive and palatable attributes, it is conceded, by all who know it, to possess high medicinal properties, and is so recommended by the medical faculty, on account of its aperient and diuretic qualities. The same is true of its wine, when properly made, and not degraded into a sirup by the profuse artificial addition of sugar.

The celebrated chemist and scientist, Dr. Jackson of Boston, in a report of his published by the United-States Government a few years ago, predicts with undoubting assurance that in no clistant future it will be admitted to be, "not only the wine-grape of America, but the wine-grape of the world." When that clay arrives, the wild vine discovered by the bold adventurers sent out by the gifted and godlike Raleigh will have become of greater commercial and economic value to the State whose capital town bears his name, than the wonderful weed to whose soothing influ- 


\section{TOKAY VIAEYARD, FAYETTEVILLE, N.C.}

ence he became the slave, as has the world after him, - "that noxious plant," which in spite of the ridicule of philosophers, the curse of kings, the interdict of parliaments, and the anathema of popes, is to-day of more universal use than any other named one in the vegetable kinglom. These are "the words of soberness and truth," although the subject is vinous. WVe are willing to stake our reputation as a prophet upon it. A generation or two hence, at most, will render verdict indicated. The prediction is predicated no less upon its already recognized merits than upon the necessity of the case. As the natural production of the Old World is curtailed by cause over which the vintner has no control, the law of demand will necessitate it. A bona fide, genuine wine of long-recognized attributes is to-day inadequate to supply the present home demand, leaving the future out of account, and ignoring the foreign market. Where demand outstrips supply, be the commodity what it may, one of two results must follow; viz., enhanced price, or a spurious article. Notwithstanding the annual and accelerated diminution of yield, the price, all things considered, is no higher than it was a quarter of a century ago (for foreign wines). This conceded, is it not patent that a counterfeit article must have supplanted the old-time honest one, not only to meet existing home demand, but more especially to satisfy the craving of alien idiots, who will be content with nothing else than an "imported article" ?

Adulteration. - Does any cloubt the ramified and pernicious exterit to which it has of late years been carried? If any there be so credulous and besotted as to believe that label or bottle is index of contents, and who plumeth himself that he is drinking the juice of the Asiatic grape whilst he sips his Moselle, his Rhine, Marsala, or Douro, let him ask himself the question, and answer from the presumptive stand-point. If that is not conclusive, leaving facts and data out of question, we propose to call but a single 


\section{TOKAY VINEYARD, FAYETTEVILLE, N.C.}

witness to the stand out of the thousand and one who might be subponaed to establish the point at issue. The "Journal des Débats," being French, may well be consiclered an impartial witness, or, if biassed at all, to be so in behalf of the native producer instead of the foreign consumer. See what it says as culled from a late copy of "The London Times."

If, after reading it, any still prefers to drink the vile decoctions palmed off on an unsuspecting world, then all that can be said is, that there is no accounting for taste. If convinced of the abomination, does it not behoove him to be very cautious of foreign wines? If, after being convinced by such unimpeachable evidence, he still persists in clinging to his high-priced Sauterne, Champagne, or Hungary, then may it be said of him, as was said of another in other days, "Ephraim is joined to his idols: let him alone." If the question be asked, Whence any better assurance of purity in native than in foreign wines? the answer would naturally be, Lower price holds out less incentive to adulterating rascality. Besides, the American producer, being comparatively a new beginner, is not up to "the tricks of the trade" of the Old-World culturist. The most harmless counterfeit wine which Europe sends us is the native American, which is palmed off uncler foreign labels to an ever credulous public at two or three times the original price. As long as fools can be found to set such value upon the impress of a cork, or the lettering of a card, it will not be otherwise. But call the French witness, and let us hear what he has to say:

"The Adultcration of Wine. - A question which greatly interests the producers of wine, but more especially the consumers of wine, in France, is now attracting public attention and the press. Several among the wine-merchants of Paris have held a great meeting at the Cirque d'Hiver, under the presidency of M. Duvergier, who made a very long speech, in which he did his best to defend the wine-trade from the accusations springing from all sides against 


\section{TOKAY VINEYARD, FAYETTEVILLE, N.C.}

the poisonous liquid sold for wine. The writing of M. Henri de Parville, which has appeared in the scientific fcuillcton of the 'Journal des Débats,' will not encourage people to drink what is now sold for French wine. He says, 'The fabrication and adulteration of the wine commences when the liquid is prepared, to render it clear, and apt for preservation. Previous to its filteration, it is mixed with albumen, gelatine, blood, and milk. These substances agree with the tannin, and are used to modify some wines. Sometimes the tannin is not sufficient, and is replaced by other poisonous ingredients. Very often "alum," a strong poison, is added to give the wine a flavored taste. In order to obtain the flavor to which the palate of foreign consumers, and especially of the English and American, is accustomed, oxide of lead is added to destroy the acidity. Alcohols produced from corn are added to increase its strength. Arsenic, sulphuric acid, and tartaric acid are added to give it color.' The writer dwells at length on the subject ; and his revelations have quite startled the Parisians, and ought to startle the British public, who are one of the greatest consumers of these poisonous drinks. After pointing to the immense damage done to public health by the wine-manufacturers of France, the 'Intransiegeant' declares that it cares far more for the health of the public than the reputation of the French winc-trade, and concludes, "What interests us most in this question is not the winetraders but the consumers. The "honor of the trade" has neither palate nor stomach, nor father, mother, wife, and children; "honor of the trade" knows nothing of inflammation of the bowels, and nobody has seen the aforesaid "honor" die from the effects of colic. The worst agonies of this "honor of the trade" will always be more insignificant than the mildest pains supported by the last of the consumers. Therefore, at a time when not one of the public administration fulfils its cluties, in which incorruptibility is nothing but a dream, in which it is no longer monstrous to be monstrous, 


\section{TOKAY VINEYARD, FAYETTEVILLE, N.C.}

we feel it our duty to congratulate the Laboratoire Municipal on its courage for refusing its protection to the poisoners of the people." " - London Times.

\section{PRICE-LIST.}

\section{WINES IN WOOD.}

White Sweet Scuppernong. . . . \$I 0 White Dry Scuppernong . . . . I 00 Red Sweet Scuppernong . . . . 100 Red Dry Scuppernong . . . . . 100 White Sweet Delaware . . . . 125 White Dry Delaware. . . . . . 125 Red Sweet Meisch . . . . . . 125 Red Dry Meisch . . . . . . 125 White Sweet Tokay . . . . . . 125 Red Sweet Concord . . . . . . 125 Red Dry Concord . . . . . . 125 Carolina Rose . . . . . . . 125 Claret . . . . . . . . . 100 Port. . . . . . . . . . I 25 Sherry. . . . . . . I 25 Muscatel . . . . . . . . I 25 Sacramental . I 00

\section{WINES IN GLASS.}

PER DOZ. White Sweet Scuppernong, 6’s . \$4 $\$ 50$ White Dry Scuppernong, 6's . . . 450 Red Sweet Scuppernong, 6's . . . 450 ked Dry Scuppernong, 6's . . . . 450 White Sweet Delaware, 6's . . 500 White Dry Delaware, 6's . . . 500 Red Sweet Meisch, 6's . . . . 500 Red Dry Meisch, 6's . . . . . 500 White Sweet Tokay, 6's. . . . 500 Red Sweet Concord, 6's . . . . 500 Red Iny Concord, 6's . . . . . 500 Carolina Rose, 6's . . . . . 500 Claret, 6's. . . . . . 450 Port, 6's . . . . . . 500 Sherry, 6's . . . . . 500 Muscatel, 6's . . . . . 500 Sacramental, 6's . . . . . . 450 Champagne (quarts) . . . . . 900 Champagne ( 2 doz. pints.). . . . 1000

\section{TO PURCHASERS.}

We warrant our Sweet Wines not to turn sour on draught. Our Dry Wines in reood are the same frices as the Sweet: but we cannot warrant them against twrning sour on dranght, and, if ordered in wood, are always sent at purchaser's risk. No light Dry IVines, cither native or forcign, will kect on draught, hence, if ordered in wood, should be bottled.

No charge for package if ordered by the barrel. If in less quantity than a barrel, one dollar for each package wiil be charged.

We spare no pains or expense to make our wines of a standard and uniform quality, and trust you will farior us with your orders.

Orders will be filled promptly. A liberal discont to the trade.

Tery respectfully,

W. J. GREEN. 


\section{EXTRACTS}

\section{FROM \\ United States Consular Reports.}

IVE deem a few extracts from the able and exhaustive Report of Hon. Thomas Wilson, consul at Nantes, France, entirely apposite to the subject. (See Reports from the Consuls of the United States, No. 27, January, I883.) “. . . This portion of this Report is intended to deal with this question in its relation to French wines and liquors, to show that they have been adulterated, have been made deleterious, if not poisonous, and as such exported to foreign countries, the United States among the rest, and, if the policy of reprisal should be adopted, that French wines and liquors as at present manufactured would be a proper subject. . . . Everybody knows or says that the wines and liquors of France are adulterated, and they deprecate it; but the consumption and use of the adulterated article go on much the same as if no adulteration existed. I shall endeavor to give some information from statistics furnished by French authorities, and so not to be controverted, showing the extent to which this adulteration is carried, and in some slight degree its effect upon the people.

"... France is the greatest wine-producing country in the world. The total production and commerce in wine for 1882 amounted to $2,056,692,49$ I francs (about $\$ 410,000,000)$. . . . 


\section{TOKAY VINEYARD, FAYETTEVILLE, N.C.}

"In I 879 commenced seriously the ravages of the national plague, - the phylloxera. Without study, one cannot appreciate the extent of the ravages, nor the great clamage this inflicted on France. In I 879-80 it utterly destroyed 1,250,000 acres of fullbearing vines. It seriously damaged about $1,250,000$ acres more. It reduced the wine-crop to $25,000,000$ hectoliters in 1879 , being a loss of about $800,000,000$ of gallons, to say nothing of Eau de vie, Cognac, etc.

[Note. - Observe the traffic in the article before and since this tremendous diminution of supply began, and say does it indicate a healthy source? - ED.]

\section{Total Export of Wines and Liquors.}

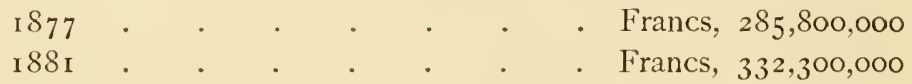

"Yet this immense failure of from five hundred to eight hundred millions of gallons, continued year after year, has had no perceptible effect on the quantity of wine drunk, the facility with which it can be obtained, nor the price to be paid for it. [See figures above.] . . . How has this great feat been accomplished? The recuperative power of France, after one year's war with Germany, and her ability to make the most out of the least, was at once the wonder and the admiration of the world; but in the case of failure of the wine-crop she has shown unexpected recuperative power, and the ability to continue it for an indefinite period.

"How has she been able to accomplish it, — this secret of making something out of nothing? Answer. They have imported in large quantities the cheap, heavy wines of Spain and Italy. They have imported raisins from Greece and Turkey, soaked them, and expressed the juice; and to these bases they add alcohol, 


\section{TOKAY VINEYARD, FAYETTEVILLE, N.C.}

coloring matter, and water in all imaginable proportions, kinds, quantities, and degrees; and thus they manufacture what they call wine, sell for wine, and export to the United States for wine.

"FAmul Secrets. - The presiclent of the tariff commission, Monsieur Pouzer-Quertier, made a speech (in the Senate), in which he set forth the true condition of France, and appealed to his colleagues to meet the tariff question fairly. He said, p. I 33, 'I have seen on the quays of Bordeaux, and I believe I can see the same to-day, a quantity of wines of Spain which had come to the borders of the Garonne. I asked of the Bordelais, if, perchance, these wines, worth only eighty or eighty-five francs per hectoliter, had not come to Bordeaux to breathe the air of Garonne, and be transformed into Mcdoc.

" This represents a certain benefit; for one must admit that this wine contains alcohol to fifteen degrees, and that, with one barrel of it and one of the water of the Garome, they make two barrels of icine.' At this, the minister of agriculture and commerce takes fire. Hear him. 'I remark to the Hon. M. Pouzer-Quertier, that it is a singular fashion to defend the industries of a great country like France to come here and tell, apropos of our wines, of the mélanges which are made with the water, the mixing . . [protestations from divers benches], and to come here To THus DISCREDIT IN THIS TRIBUNE THE FRENCH PRODUCTS DESTINED FOR FOREIGN COUNTRIES.

" In truth it is a singular faslizon for him to proced [more interruptions]. Irou understand that since two or three years, either from phylloxera, from frost, or from dropping of the fruit, we have descended from an annual production of sixty million hectoliters to twenty-eight million. It is incontestable that we have not produced the same quantity of wine; and, althongh we may add water, it is still necessary to seek in foreign countries that which 


\section{TOKAY VINEYARD, FAYETTEVILLE, N.C.}

we have lost."" Mr. Wilson continues, "I have shown enough to raise a presumption of its wholesale manufacture.

"I have shown, (I) the failure of the crop sufficient to produce a famine; (2) no diminution in either consumption or exportation; (3) no corresponding increase in price; (4) an immense increase in importation of the (known to be) heavy wines of Spain and Italy; and (5) the entire making of the crop of raisin-wine, the two latter being in sufficient quantities in the aggregate to make good the deficit; $(6)$ that the charge of this wholesale manufacture was made publicly in the Senate of France, and several senators shouted, in support of it, that 'all the world knew it to be so; (7) the minister of agriculture and commerce, replying to the senator, did not deny the charge, but upbraided the senator for making it, and said, if it was true, it had its justification. . . . A French chemist once said, "Wine is a mixture of alcohol and sugar and water; but,' added he, 'mixing alcohol and sugar and water will not make wine.' . . . Wine has been falsified and adulterated in all ages; but, until twenty years ago, it was done so clumsily, that its detection was easy. Most wine-dealers would detect it by the taste, or, if not, at the expense of a piece of creamof-tartar.

"All this has been changed. Now the falsificators profit by and make use of all the progress of modern chemistry; and the art of making wine without the juice of the grape has attained such a degree of perfection and skill, that experts, epicures, and chemists alike are baffled, and hesitate before pronouncing.

"M. Girard, director of the Laboratoire Municipal at Paris, probably the foremost authority in Europe or the world, says in his official report, amongst other things denunciatory of wholesale adulteration, 'After attempting to pass a large quantity of water under the name of wine, they add to the monillage the alcohol of an inferior quality of potatoes or beets, which contains alcohol 


\section{TOKAY VINEYARD, FAYETTEVILLE, N.C.}

AMYLIQUE, which produces a drunkenness far worse than that produced by the alcohol of wine. These, with all their ramifications, are not the only falsifications: the body, the aroma, the bouquet, of the finest qualities of grand wines, are imitated on a large scale by scientific process. . . Each day the chemist is met by new difficulties. He is obliged to labor without cessation to perfect his methods to combat those who dishonor science by using her to perpetrate frauds.'

“.. This inspection was principally for wines colored with fuchsine, it being known or determined that no combination of that article but was poisonons.

The result of that inspection was as follows :-

Number of establishments inspected, 300 ; number of hectoliters confiscated, 3,307 (or about 85,000 gallons), all being wine fuchsine; proportion of samples found $b a d, 59$ to I 7 per cent; not poison, 2.309 samples; poison, 977 samples.

"Can it be wondered that "insanity from alcoholism has increased from seven to fourteen per cent,' or double?" - Rcport of Minister of Fustice.

These extracts tally entirely with the reports of the consuls at La Rochelle and other wine ports of France.

If forty per cent of the wines sold in Paris are poisonous, as per report of Inspector, is it not safe to assume that at lcast an equal proportion of that exported to foreign countries properly ranks under the same head?

[New-York Evening Post, Feb. 9.]

\section{CALIFORNIA WINES.}

THE trade journals are again directing attention to the fact that a large proportion of wine sold in this country as foreign wine is produced in California, and sold in bottles labelled with imitation 


\section{TOKAY VINEYARD, FAYETTEVILLE, N.C.}

foreign labels. A Beaver-street wine-merchant said yesterday, in speaking of the matter, "The chief trouble is, that the middlemen, the wholesale wine-merchants, who buy from the wine-maker, and sell to the retailer, are interested in keeping up the deception; because by means of it they are enabled to buy cheap, and sell dear. It is to their advantage to cry down American wines as inferior to foreign products; and, when one tries to sell American wines for what they really are, he finds more opposition from the men who sell American wines under foreign names than from the few houses which really deal in foreign products. Every possible trick is resorted to for the purpose of disguising the fact that the wine sold is California wine. Even in San Francisco, where some local pricle might be expected to help the sale of native wines, they are bottled, and sold largely with French labels, some being imitations of labels of celebrated houses, and others being more innocent of deception, because they do not steal trade-marks." Since the passage of an Act imposing a fine of five hundred dollars for selling wine with forged labels, the fraud is carried on more carefully; and cases of bottles are sent by wine-merchants to retail dealers without labels, and the labels are sent separately, and are pasted on according to the demands of customers. One case of American wine can by this system make a label do service for half a dozen French brands. In nine cases out of ten, according to a letter recently published in the "Wine and Fruit Grower,"

what is sold as French wine in California is made there. The immense profit in deception is what keeps it up. The effect is detrimental to wine-makers, who do not reap any advantage from the increased consumption of their wines. I have seen in the bottling-rooms of California wine-merchants small mountains of bottles, out of which very few could be picked which were not ornamented with spurious labels. The manager of an establishment said to me, "These bottles come from all parts of the State. 


\section{TOKAY VINEYARD, FAYETTEVILLE, N.C.}

You see that they all have foreign labels, and doubtless their contents were sold as imported wine." Taking up a bottle incliscriminately, I read such labels as "Cantenac Medoc, i 864, D. Misett, Bordeaux ;" "Margaud Medoc, IF. Keppler \& Cic, Bordeaux." A San Francisco bottle of Sauterne was branded on the cork, "Pouget Fils, Bordeaux." It was a genuine bottle, and had a San Francisco label of "Cantenac, Pouget Fils, Bordeaux." On a California-made bottle was a label of what purported to be German Hock. " "Rouen Thaler, F. Weller \& Co., Maenz," was stuck on a Fench Claret bottle. An imitation of a Château La Rose label could be bought in San Francisco at seren dollars a thousand. There might be read on a good many a facsimile of the "Duc de Montebello." The label might be seen on a California bottle, and on another a label of an imaginary firm, "E. Blossiear \& Cie, Rhiems."

A dealer in nothing but California wines, who sells them as such, and is trying to educate the public taste to like it under its true name, said the California wine-blenders have themselves to thank for the present conditions of affairs. Instead of devoting themselves to making a pure wine, they attempted to try all kinds of devices to imitate European wines in color and flavor, and thus played directly into the hands of the importers. As to the fact that an enormous quantity of California wine is sold under foreign labels, there is no doubt of it whatever. Any wine-merchant will admit that not one-twentieth of the wine sold to consumers in this country in 1880 was sold as American. Four hundred and fifty thousand gallons were sold in one month to foreign importing houses in this city, - a hundred thousand gallons to a Spanish firm, who would deny point blank having any thing to do with such "stuff" as American wine. The only remedy is for wine-producers to establish their own agencies, and create a demand for native wines. 


\section{TOKAY VINEYARD, FAYETTEVILLE, N.C.}

[American Wine and Grape Grower.]

\section{AMERICAN WINES.}

If there were needed any sufficient reason for Americans to look with favor upon the products of their own native vineyards, and with disfavor upon foreign wines, the fact that our wines are the pure juice of the grape, and foreign wines impure and sophisticated abominations, should fumish that reason. American winemanufacture is a new art, but even at this early clay our product has reached to one-half of our consumption. Last year we made six million gallons, and imported precisely the same quantity. Unfortunately, so persistently prejudiced are the American people in favor of imported foreign products, that the greater part of the American-made wines are sold as choice foreign kinds, with false brands upon them. The bulk of the real foreign wines is vastly inferior. But "who hath believed our report" when we have reiterated time and again this fact? And now we have some fresh evidence of the same sort, only, so to speak, "more so." It comes from foreign parts, and is imported direct from Paris, and should therefore be received at least with as much confidence as the French wines themselves. This report, taken from statistics of the Paris Municipal Laboratory, where the food analyses required by law are made, shows among other facts that in the month of June 455 samples of wine were examined; and of these but 14 were found to be good, I 23 were reported tolerable, and 3 I 8 bad. Of 455 samples, but I4 were good. If the French people this treat themselves, what consideration might a foreigner expect, and how many samples of real imported wines (excluding the American sold for foreign) might be found to be even tolerable, and without any distinct shade of goodness at all? 


\section{TOKAY VINEYARD, FAYETTEVILLE, N.C.}

[New-York Star, June 9, $15 S_{3}$.]

\section{BAD WINE.}

IT appears that the consumption of wine in England has fallen off four and a half million gallons in seven years. In 1876 it amounted to eighteen and a half million gallons; but last year it had dropped to fourteen million. The chief cause of this marked decline is said to be the deterioration of the wines in quality. They are cloctored too much. The adulterations are not only deleterious, but patent and offensive. It has been said more than once in England, that it would be impossible to get pure Port wine, were a man to see it made at the vineyard, and shipped for home, riding all the way on the head of the cask. However that may be, the fact that many of the costly wines of England are badly adulterated is well known there and here; while the cheap wines fare better, because it does not pay to adulterate them. It would be strange indeed if the adulteration of wines and liquors should stop their sale, and encourage temperance. But the facts look in that direction. 





\section{PRESS OF}

RAND, AVERY, \& CO., BOSTON, MASS.

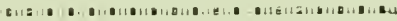




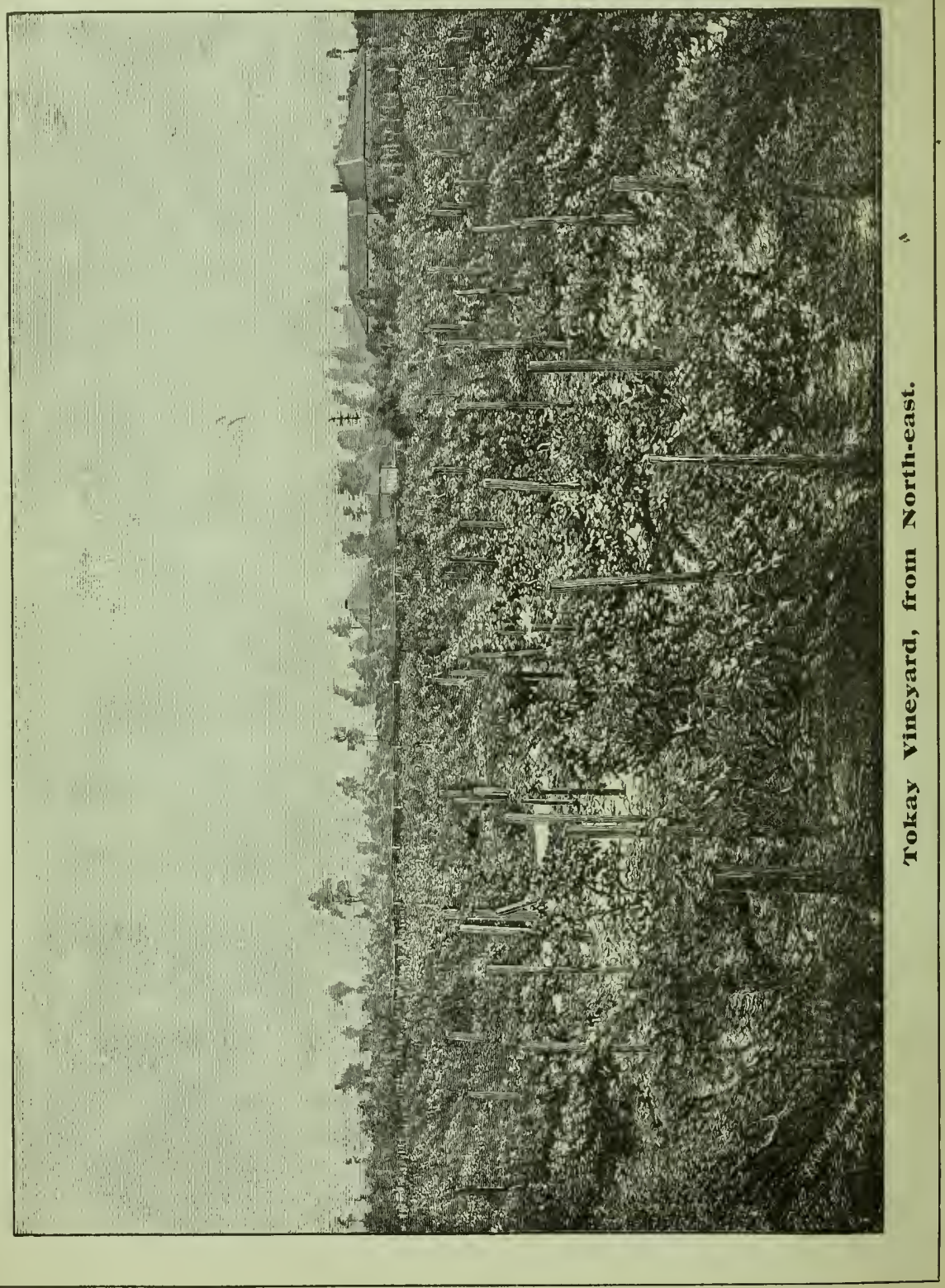







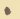





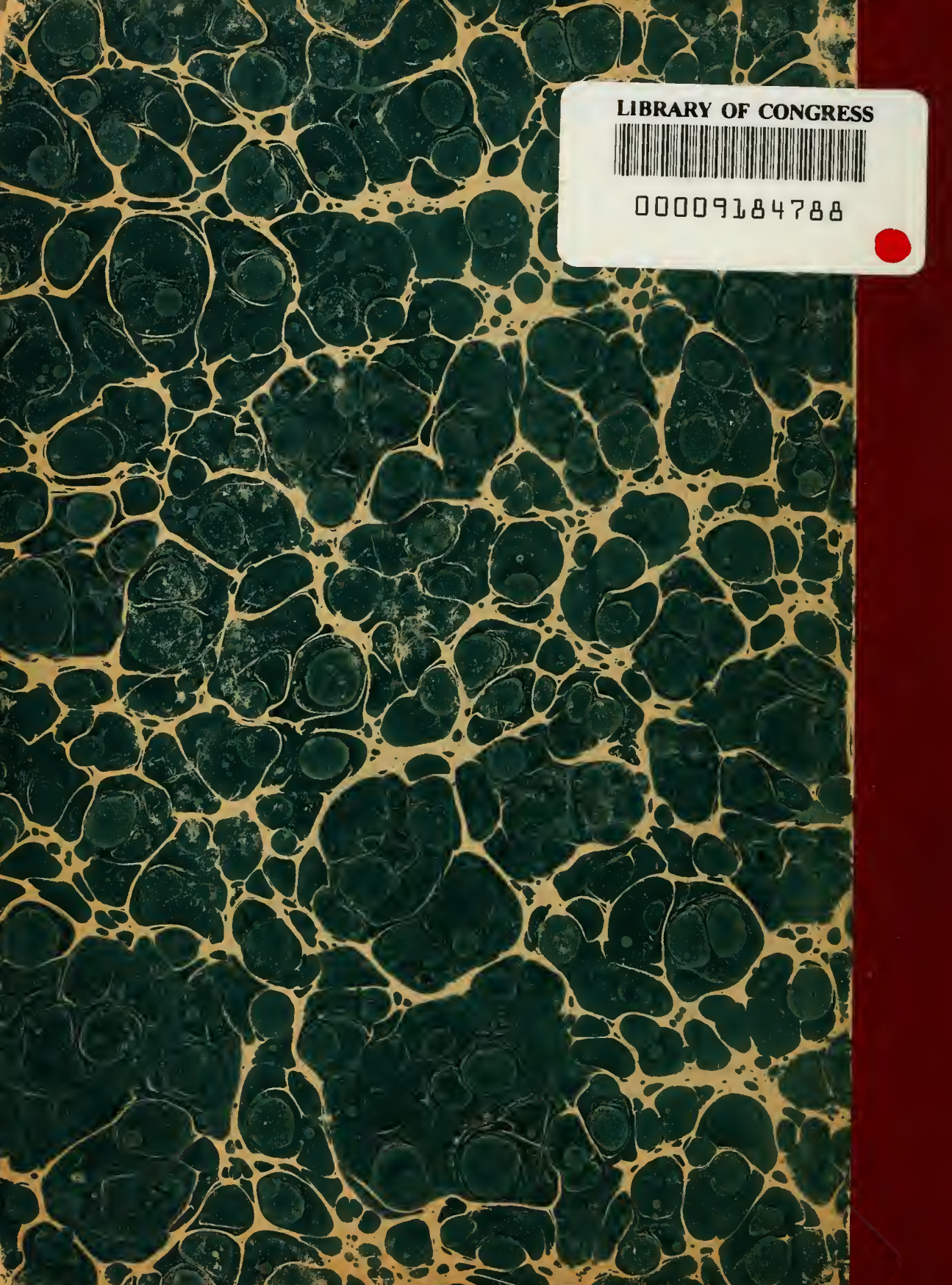

